\title{
Scientific Approach to the Formation of Personnel Competence Models for the Russian Military Industrial Complex in the Conditions of Production Diversification
}

\author{
Tatyana A. Berkutova ${ }^{1 *[O R C I D ~ 0000-0003-3357-7845], ~}$ \\ Boris A. Kovtun 1[ORCID 0000-0002-1072-6134], \\ Anastasia V. Makhova 1[ORCID 0000-0002-6775-5243], \\ Artem E. Poikin 1[ORCID 0000-0001-6185-8922], \\ Kirill A. Sidorov 2[ORCID 0000-0002-2268-1789]
}

\author{
${ }^{1}$ All-Russia Scientific and Research Institute "Center”, Moscow, Russia \\ ${ }^{2}$ Ministry of Industry and Trade of the Russian Federation, Moscow, Russia \\ tberkutova@yandex.ru
}

\begin{abstract}
The article presents the results of a study of the formation of personnel competence models for enterprises of the military-industrial complex in the context of diversification. The authors carry out a comparative analysis of the goals of diversification and the content of marketing activities. The use of a competency-based approach was substantiated, and a survey of heads of enterprises of the military-industrial complex was conducted on the composition and content of knowledge, skills and abilities necessary for effective work in the markets of hightech civilian and dual-use products. Models of competencies for personnel of strategic, tactical and operational levels of marketing activities at enterprises of the military-industrial complex are proposed. In the structure of competencies for personnel of the strategic level of marketing activities, the predominance of knowledge, skills and abilities in the formation of the value of a business, its long-term stability and innovation in the markets of high-tech civilian and dual-use products is substantiated. As part of the tactical level of marketing activities, competencies are proposed that allow you to develop and implement marketing strategies, carry out tactical and operational management of work with markets, goal-setting, and the formation of teamwork. As part of the operational level of marketing activities, competencies related to direct interactions with target buyers and consumers, such as the ability to negotiate and carry out sales, Internet marketing, and the ability to conduct market research, are proposed as prevailing. The proposed scientific approach makes it possible to form models of market personnel competencies for enterprises of the military-industrial complex in the context of various industries for the strategic, tactical and operational levels of personnel on the basis of clarifying the goals of marketing activities in the context of achieving the goals of diversification of enterprises of the militaryindustrial complex.
\end{abstract}

Keywords: military-industrial complex, diversification of production, market competencies of personnel, marketing activities in the process of diversification

\section{INTRODUCTION}

At present, the task of diversifying the enterprises of the military-industrial complex (hereinafter - MIC) is set at the state level: the share of civilian products in the total output of the domestic MIC in 2025 should be at least $30 \%$, and in 2030 - at least $50 \%$. Despite the positive nature of the dynamics of the rate of production of high-tech civilian and dual-use products (hereinafter - 
HTCDP) in the structure of the defense industry (Table 1), the main factors hindering the intensification of diversification processes, according to the heads of defense enterprises, are factors associated with a lack of market competencies (Table 2).

Table 1. The share of HTCDP in the total output of MIC products

\begin{tabular}{|l|c|c|c|c|c|c|}
\hline \multirow{2}{*}{\multicolumn{1}{|c|}{ Industry Sector }} & \multicolumn{2}{|c|}{2018} & \multicolumn{2}{c|}{2019} & \multicolumn{2}{c|}{2020} \\
\cline { 2 - 7 } & $\begin{array}{c}\text { Rate of } \\
\text { change in } \\
\text { HTCDP, \% }\end{array}$ & $\begin{array}{c}\text { Share of } \\
\text { HTCDP in } \\
\text { the total } \\
\text { volume, \% }\end{array}$ & $\begin{array}{c}\text { Rate of } \\
\text { change in } \\
\text { HTCDP, \% }\end{array}$ & $\begin{array}{c}\text { Share of } \\
\text { HTCDP in } \\
\text { the total } \\
\text { volume, \% }\end{array}$ & $\begin{array}{c}\text { Rate of } \\
\text { change in } \\
\text { HTCDP, \% }\end{array}$ & $\begin{array}{c}\text { Share of } \\
\text { HTCDP in } \\
\text { the total } \\
\text { volume, \% }\end{array}$ \\
\hline MIC in general & 104.8 & 23.1 & 106.5 & 24.1 & 101.2 & 25.6 \\
\hline Aviation Industry & 101.7 & 34.1 & 87.3 & 31.3 & 96.2 & 31.4 \\
\hline Conventional Arms Industry & 106.6 & 22.4 & 103.6 & 21.6 & 77.6 & 21.4 \\
\hline $\begin{array}{l}\text { Ammunition and Special } \\
\text { Chemicals Industry }\end{array}$ & 96.7 & 25.8 & 103.6 & 26.7 & 99.7 & 26.7 \\
\hline Shipbuilding Industry & 118.3 & 15.3 & 162.6 & 25.8 & 116.2 & 28.7 \\
\hline Radioelectronic Industry & 108.7 & 12.3 & 144.7 & 15.0 & 116.7 & 18.2 \\
\hline
\end{tabular}

Source: Data provided by the All-Russia Scientific and Research Institute "Center"

Table 2. Results of a survey of heads of MIC enterprises

\begin{tabular}{|l|c|}
\hline $\begin{array}{c}\text { Factors Hindering the Intensification of the Processes of Diversification of MIC } \\
\text { Enterprises }\end{array}$ & $\begin{array}{c}\text { Percentage of Respondents Who } \\
\text { Indicated the Factor, \% }\end{array}$ \\
\hline $\begin{array}{l}\text { Lack of competencies in working with markets (difficulties in choosing markets, } \\
\text { forming strategies, entering markets, promoting the HTCDP) }\end{array}$ & 76 \\
\hline Difficulties with the development of a new HTCDP & 51 \\
\hline Difficulties in mastering production & 36 \\
\hline Lack of government support measures & 29 \\
\hline
\end{tabular}

Source: Compiled by the authors

The structure and composition of market competencies, personnel is determined by the specifics of diversification goals [1-3], which include:

- entering the HTCDP markets (global and domestic);

- increasing the competitiveness of MIC enterprises in the markets;

- formation of a balanced product portfolio of HTCDP;

- coordination of interests of military and civilian production;

- transition of MIC enterprises to a modern business model;

- increasing the innovative activity of MIC enterprises;

- increasing capitalization and investment attractiveness;

- increasing the mobility and adaptability of MIC enterprises to market conditions.

The presented set of goals determines the content of the marketing and management activities of the defense industry enterprises in the context of entering the HTCDP markets.

Creation and implementation of personnel competency models should ensure the transition to a modern business model, which will allow enterprises to achieve stable financial results in the HTCDP markets in the strategic period (due to mobility, flexibility, adaptability, development of assets that form the value of the business) [3-7]. Market competencies of personnel will determine the ability of the business to integrate into a dynamically changing external environment, focus on consumer interests, create and use market partner assets to achieve competitiveness, stimulate the innovativeness of the enterprise.

In the process of diversification development, it is important to ensure not only the presence of professional qualities of the personnel of marketing, sales, development services, but also the understanding of the business tasks by the employees, the ability to manage the achievement of diversification goals, and to form strategic directions of activity in the HTCDP markets.

The main advantages of the competency-based approach are:

- the possibility of forming competency models for the business tasks of the enterprise in the context of diversification;

- comprehensive coverage of the characteristics of employees (professional, 
personal, general, corporate competences, etc.);

- the possibility of using competency models, both at the stage of personnel selection and at the stages of certification, assessment, formation of a personnel reserve, career planning, training.

The competence-based approach describes not only the knowledge and skills of the employee, but also the behavior and actions, takes into account the employee's ability to bear responsibility, understanding the result, the possibility of implementing managerial skills [8-10].

In the process of forming personnel competency models, four groups of goals are taken into account (Figure 1).

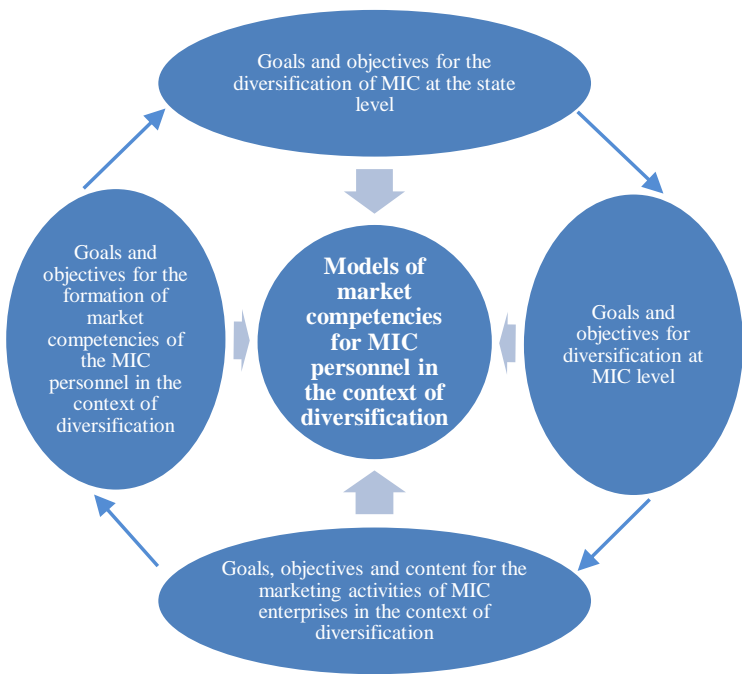

Figure 1. Factors affecting the formation of market competencies of MIC enterprises in the process of diversification

Source: Compiled by the authors

\section{MATERIALS AND METHODS}

The aim of the study is to develop a scientific approach to the formation of market competencies of MIC enterprises in the context of diversification.

The research objectives include:

- defining the functions of marketing at the MIC enterprises;

- defining the tasks of the MIC marketing services personnel;

- determine the directions for the formation of market competencies in the context of diversification.
The research methodology is determined by a set of scientific methods, as well as by the goal, objectives and principles of the formation of competencies in the process of diversification of the MIC industry.

The methodological basis of the study was the scientific work of Russian and foreign scientists on the diversification of MIC enterprises, the content of marketing activities, and the formation of competency models.

In the course of the study, a systematic and integrated approach, methods of comparative and factor analysis, methods of interviewing heads of MIC enterprises, and a competency-based method in personnel management were used. In the course of the study, the types of marketing activities in the context of the diversification of the defense industry were structured, a comparative analysis of the goals of diversification and marketing activities was carried out.

When forming the composition of competencies required in the course of MIC diversification, their main groups were identified: corporate, professional, general, personal, communication.

The research results can be applied in various branches of MIC in the process of diversification.

In the course of the study, we used the results of interviews with heads of MIC enterprises, statistical data, databases of the Federal State Unitary Enterprise All-Russia Scientific and Research Institute "Center".

\section{RESULTS}

The selection and justification of the market competencies of employees engaged in the diversification of MIC enterprises should be based on an analysis of the content of marketing activities.

Analysis of publications on the content of marketing allows us to determine the systemic and evolutionary nature of marketing activities and consider it as a universal system of tools for working with the market and business management, the elements of which are used situationally, depending on the prevailing external and internal conditions $[3$, $6,11,12]$.

Based on the generalization of the results of scientific research in the field of development and content of marketing, the author's understanding of marketing activities was formed as:

- a system for the formation and improvement 
of business efficiency, ensuring its mobility and adaptation to the external environment, stability of financial flows, reduction of volatility based on the integration of marketing into the strategic management system of the enterprise, creation of the market value of the business through marketing intangible assets and the use of partner resources; development of market network interactions;

- a function of the enterprise, involving the analysis of markets, the development and implementation of marketing and market strategies (product, price, promotion and sales strategies, positioning and segmentation);

- a system of interconnection of internal and external counterparties in the process of functioning of the business model of the enterprise.

Marketing activities at enterprises are carried out at the strategic, tactical and operational levels, each of which is characterized by a different composition of functions that require differentiation of personnel competencies (Figure 2).

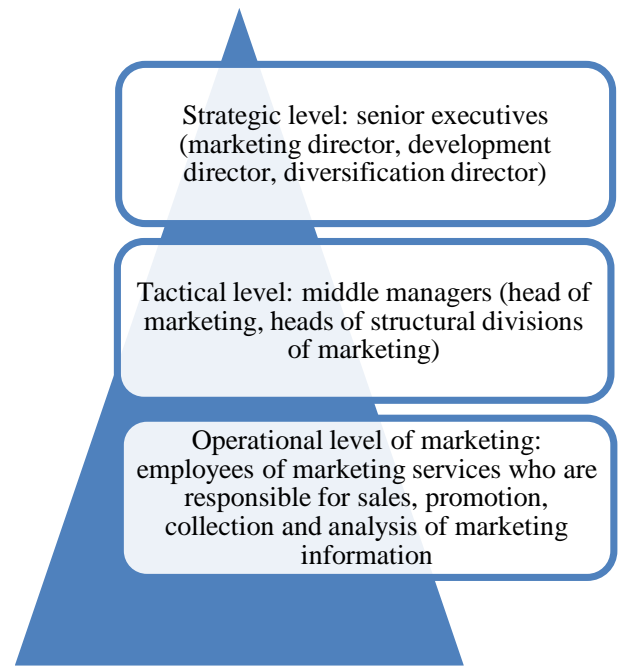

Figure 2. Levels of marketing activities at MIC enterprises

Source: Compiled by the authors

Analysis of the content of marketing activities allows us to determine the following functions at the MIC enterprises in the process of diversification:

1) Strategic level:

- identification and selection of strategic markets for HTCDP;
- defining market and competitive strategies for HTCDP;

- formation of the product portfolio of HTCDP;

- formation of business models to achieve market goals;

- formation of market partnerships;

- strategies for the formation of marketing intangible assets (trademarks, brands, channels of interaction);

- increasing the value of the business;

- formation of the company's position in the process of communication with legislative and executive authorities, development institutions, and other target audiences.

2) Tactical level:

- positioning of the MIC enterprises in the HTCDP markets;

- formation of marketing strategies (product, price, service, promotion and sales strategy);

- evaluation of the effectiveness of marketing activities.

3) Operational level:

- sales activities;

- promotion of the HTCDP (including the Internet);

- collection and analysis of marketing information.

The composition and structure of personnel market competencies are also determined by the following factors:

1) Factors of the macroenvironment:

- state policy in the field of MIC diversification;

- $\quad$ strategy of diversification of Russia;

- regulatory and legal framework in the field of MIC diversification;

- government measures to support and stimulate the MIC diversification;

- activities of development institutions;

- conjuncture of foreign and domestic markets;

- sanctions policy in relation to the Russian Federation;

- policy of technological independence and import substitution. 
2) Factors of the microenvironment:

- types of HTCDP markets in which the MIC enterprise operates and plans to operate (B2B, B2C, B2G);

- degree of novelty and dynamics of markets;

- the composition of competitors and the level of competition;

- the presence and composition of partner organizations.

3) Factors of the internal environment:

- goals and functions of the marketing activities of the enterprise;

- the composition of the divisions of the marketing service of the MIC enterprises;

- internal requirements for personnel;

- availability of resources for the implementation of diversification processes.

The result of the study is the choice of directions for the formation of market competencies for personnel of the strategic, tactical and operational level of marketing activities of MIC enterprises (Table 3-5).

The competencies of the personnel who make decisions at the strategic level of marketing activities make it possible to formulate business tasks, build a business structure for them, determine strategic goals and ways to achieve them in the HTCDP markets.

Table 3. Directions of the formation of market competencies for personnel of the strategic level of marketing activities in the process of MIC diversification

\begin{tabular}{|c|c|}
\hline $\begin{array}{l}\text { Types of } \\
\text { Competencies }\end{array}$ & Competencies \\
\hline Corporate & $\begin{array}{l}\text { Ability to apply knowledge about: the company's products, production, technological and logistics } \\
\text { capabilities, design and service capabilities }\end{array}$ \\
\hline General & $\begin{array}{l}\text { Systems thinking } \\
\text { Analytical thinking } \\
\text { Ability to apply theoretical knowledge } \\
\text { Teamwork }\end{array}$ \\
\hline Professional & $\begin{array}{l}\text { Ability to develop market strategies in domestic and foreign markets } \\
\text { Ability to form and select strategic alternatives in the HTCDP markets, taking into account the factors of the } \\
\text { external and internal environment } \\
\text { Ability to form a product portfolio for the HTCDP } \\
\text { Ability to design business networks } \\
\text { Ability to determine the development and management of marketing intangible assets } \\
\text { Ability to work effectively with measures of government support for diversification } \\
\text { Ability to represent the company in the course of targeted communications with the subjects of the external } \\
\text { environment (government organizations, buyers, suppliers, intermediaries, representatives of development } \\
\text { institutions, etc.) } \\
\text { Ability to lobby for the goals of the enterprise in the legislative and executive authorities } \\
\text { Predictive ability for HTCDP markets }\end{array}$ \\
\hline Communicative & $\begin{array}{l}\text { Ability to carry out effective communications with stakeholders (government authorities, shareholders, } \\
\text { company management, personnel, business partners) } \\
\text { Negotiation activity }\end{array}$ \\
\hline Personal & $\begin{array}{l}\text { Self-development ability } \\
\text { Ability to achieve a goal }\end{array}$ \\
\hline
\end{tabular}

Source: Compiled by the authors

The competencies of the personnel who make decisions at the tactical level of marketing activities make it possible to translate strategic decisions into the plane of marketing plans, strategies for the entire marketing mix, and specific events. Tactical level managers form roadmaps to achieve goals for each strategic market, determine the composition of personnel, motivation methods, decompose strategic goals to the level of tactical and operational components, and distribute goals among employees of the operational level. Managerial competencies provide the ability to manage a team, set and achieve goal.

The competencies of personnel at the operational level of marketing activities are primarily aimed at establishing targeted interactions with buyers and consumers (existing and potential). As part of such interactions - the transfer of information, the execution of sales transactions, clarification of the needs of buyers, the receipt and analysis of data about markets, goods, customers, competitors, and the macro environment. 
Table 4. Directions of the formation of market competencies for personnel of the tactical level of marketing activities in the process of MIC diversification

\begin{tabular}{|l|l|}
\hline \multicolumn{1}{|c|}{$\begin{array}{c}\text { Types of } \\
\text { Competencies }\end{array}$} & \multicolumn{1}{c|}{ Competencies } \\
\hline Corporate & $\begin{array}{l}\text { Ability to apply knowledge about: the company's products, production, technological and logistics } \\
\text { capabilities, design and service capabilities }\end{array}$ \\
\hline General & $\begin{array}{l}\text { Systems thinking } \\
\text { Analytical thinking } \\
\text { Ability to apply theoretical knowledge } \\
\text { Teamwork }\end{array}$ \\
\hline Professional & $\begin{array}{l}\text { Ability to identify and structure the needs of HTCDP markets } \\
\text { Ability to develop and implement a product strategy } \\
\text { Ability to develop and implement a pricing strategy } \\
\text { Ability to develop and implement a promotion strategy } \\
\text { Ability to develop and implement a sales strategy } \\
\text { Ability to develop and implement a service strategy } \\
\text { Formation of databases } \\
\text { Ability to create a marketing information system at a MIC enterprise } \\
\text { Ability to work effectively with government support for diversification }\end{array}$ \\
\hline Managerial & $\begin{array}{l}\text { Team building } \\
\text { Goal-setting } \\
\text { Ability to develop and implement marketing plans } \\
\text { Ability to apply staff motivation methods } \\
\text { Creation of effective communications both within the marketing service and with other departments } \\
\text { Ability to manage conflicts }\end{array}$ \\
\hline Communicative & $\begin{array}{l}\text { Ability to generate targeted customer interactions } \\
\text { Stress tolerance }\end{array}$ \\
\hline Personal & $\begin{array}{l}\text { Leadership } \\
\text { Self-development ability } \\
\text { Ability to achieve a goal }\end{array}$ \\
\hline
\end{tabular}

Source: Compiled by the authors

Table 5. Directions of the formation of market competencies for personnel of the operational level of marketing activities in the process of MIC diversification

\begin{tabular}{|c|c|}
\hline $\begin{array}{c}\text { Type of } \\
\text { Competencies }\end{array}$ & Competencies \\
\hline Corporate & $\begin{array}{l}\text { Ability to apply knowledge about: the company's products, production, technological and logistics } \\
\text { capabilities, design and service capabilities }\end{array}$ \\
\hline General & $\begin{array}{l}\text { Systems thinking } \\
\text { Analytical thinking } \\
\text { Ability to apply theoretical knowledge } \\
\text { Teamwork }\end{array}$ \\
\hline Professional & $\begin{array}{l}\text { Ability to sell HTCDP } \\
\text { Customer focus } \\
\text { Negotiation activity } \\
\text { Conducting surveys, interviews, focus groups } \\
\text { Ability to design and conduct marketing research of HTCDP markets } \\
\text { Database maintenance } \\
\text { Ability to choose promotion channels and transmit information through them } \\
\text { Ability to create information and advertising messages } \\
\text { Ability to ensure efficient operation of Internet communications } \\
\end{array}$ \\
\hline Communicative & $\begin{array}{l}\text { Ability to form targeted interactions with buyers and consumers } \\
\text { Stress tolerance } \\
\text { Ability to extinguish conflicts } \\
\text { Ability to identify customer needs }\end{array}$ \\
\hline Personal & $\begin{array}{l}\text { Result orientation } \\
\text { Responsibility }\end{array}$ \\
\hline
\end{tabular}

Source: Compiled by the authors

The proposed composition of competencies can be scaled in the formation of models in the MIC, while in the sectoral context there will be changes in the composition of tools and methods of working with the market environment, which depend on the types and number of buyers, the dynamics of the HTCDP markets and other market indicators. In particular, a number of markets for the enterprises of the radio-electronic industry are closer to the $\mathrm{B} 2 \mathrm{C}$ model, the markets of aviation and shipbuilding products are overwhelmingly represented by types $\mathrm{B} 2 \mathrm{~B}$ and $\mathrm{B} 2 \mathrm{G}$, the markets of the conventional arms industry can also be characterized as state and industrial. 
Thus, the proposed scientific approach makes it possible, on the basis of combining and interconnecting the goals of diversifying the defense industry with the content and goals of marketing in the HTCDP markets, to form models of personnel competencies for employees of the strategic, tactical and operational level of marketing services at MIC enterprises.

\section{DISCUSSION}

The issues of the composition of market competencies required to achieve the goals of diversifying the MIC industry are considered by various authors.

A number of authors consider only competencies related to the development of technical professional competencies (the ability to use new software in the course of the design of the HTCDP, the ability to develop technological processes in the context of digitalization, the ability to introduce new technological trends into practice) [5, 13-15]. Other authors consider the term "ability to work with markets", implying sales and promotion activities, active communications [6, 16]. Almost all authors note the importance of including knowledge, skills and abilities of working on the Internet (retargeting, search engine optimization, working with analytics systems) in the competence model.

As part of the general and personal competencies of employees working with markets, most authors name analytical thinking and systems thinking. This is due to the need to work with large amounts of information at each level of marketing activities, the ability to systematize information, form time series, identify trends, and identify patterns.

\section{CONCLUSION}

The proposed scientific approach makes it possible to combine the content of the professional competencies of employees engaged in marketing activities with general, personal, corporate and managerial competencies that allow MIC enterprises to achieve the goals of diversification in the HTCDP markets.

At the same time, professional competencies cover not only direct current work with consumers, but also marketing management issues, as well as issues of business value formation and its strategic nature.

The novelty of the proposed approach is to combine the goals and objectives of diversification, marketing activities and personnel management in the formation of market competencies of employees in the process of achieving the goals of MIC diversification.

\section{AUTHORS' CONTRIBUTIONS}

The authors made an equal contribution to the study: collection and analysis of material; definition of goals and objectives, research methods; formulation and scientific substantiation of conclusions, registration of key research results in the form of an article.

\section{REFERENCES}

[1] S.I. Dovguchits, D.A. Zhurenkov, "Problems of diversification of the military-industrial complex and the ways of their solutions, Scientific Bulletin of the Military-Industrial Complex of Russia, 2017, vol. 4, pp. 7-17. (In Russ.).

[2] A.M. Bat'kovsky, M.A. Bat'kovsky, A.V. Brykin, A.O. Zhukov, P.V. Kravchuk, "Improving the Management Tools for Hightech Enterprises in the Context of Production Diversification" [Sovershenstvovaniye instrumentariya upravleniya predpriyatiyami vysokotekhnologichnoy otrasli v usloviyakh diversifikatsii proizvodstva], Moscow: OntoPrint, 2021, 188 p. (In Russ.).

[3] T.A. Berkutova, "Diversification Mechanisms of Enterprises of the Military-Industrial Complex in the Conditions of Military-Civil Integration" [Mekhanizmy diversifikatsii predpriyatiy oboronno-promyshlennogo kompleksa v usloviyakh voyenno-grazhdanskoy integratsii], Izhevsk: LLC "Print”, 2017, 152 p. (In Russ.).

[4] V.V. Pimenov, "On the change in the business model of the development of the defense industry enterprises during the transition to a new state armaments program" [O smene biznes-modeli razvitiya predpriyatiy OPK pri perekhode $\mathrm{k}$ novoy gosudarstvennoy programme vooruzheniy], in Ed. by L.V. Pankova, S.U. Kazennov, O.V. Gusarova, "Military-economic Development in the Light of Global Transformations", Collection of Conference Materials, Moscow IMEMO, 2019, pp. 60-63. (In Russ.).

[5] D.A. Akimkina, "Personal potential development in an environment of innovation and diversification", International Journal of 
Humanities and Natural Sciences, 2021, vol. 61(57), pp. 149-153. (In Russ.). DOI: 10.24412/2500-1000-2021-6-1-149-153

[6] D. Klimanov, O. Tretyak, "Linking business model research and marketing: new networkbased approach to business model analysis", Journal of Business and Industrial Marketing, 2019, vol. 34(1), pp. 117-136.

[7] S.V. Chemezov, N.A. Volobuev, Yu.N. Koptev, A.I. Kashirin, "Diversification, competencies, problems and tasks: new opportunities", Innovations, 2017, vol. 4, pp. 3-26. (In Russ.).

[8] S.N. Larin, T.V. Stebenyaeva, G.S. Khudoley, "Validation of employer requirements to the level of the professional competence of skilled professional and managers", International Research Journal, 2017, vol. 3-1(57), pp. 40-43. (In Russ.). DOI: 10.23670/IRJ.2017.57.080

[9] E. Dyundik, S. Golubev, A. Makhova, L. Gurtskoy, "Development of human capital in the military industrial complex of Russia in the context of digital transformation", in Proceedings of the ISPC "Environmental Risks and Safety in Mechanical Engineering”, 2020, vol. 217, p. 06005 . DOI: 10.1051/e3sconf/202021706005

[10]N.A. Semochkina, "The problems and the prospects of economic development and training for high-tech industries", Izvestia Volgograd State Technical University, 2017, vol. 7(202), pp. 39-43. (In Russ.).
[11]P. Kotler, H. Kartajaya, I. Setiawan, "Marketing 4.0: Moving from Traditional to Digital", Kindle Edition, 2016, 208 p.

[12] M.E. Porter, J.E. Heppelmann, "Why Every Organization Needs an Augmented Reality Strategy", Harvard Business Review, 2017, vol. 95(6), pp. 46-62.

[13] Yu.Ya Boldyrev, O.A. Kartavenko, "Classification of measures for improving the training of personnel for high-tech sectors of industry" [Klassifikatsiya meropriyatiy pri sovershenstvovanii podgotovki kadrov dlya vysokotekhnologichnykh sektorov promyshlennosti], in Collection of Reports of St. Petersburg International Economic Forum, Section held in Peter the Great St. Petersburg Polytechnic University, 2019, pp. 30-32. (In Russ.).

[14] S.S. Golubev, M.Y. Veselovsky, G.I. Andryuschenko, I.V. Balynin, "Quality Transformation of High Technology Industrial Enterprises Corporative Management in Terms of Transition to Digital Technology", Quality Access to Success, 2020, vol. 21(176), pp. 3-8.

[15] A.Yu. Pronin, "Technology transfer is a tool for innovative development of the defenseindustrial complex of Russia under diversification", Vector Economy, 2020, vol. 12(54), p. 58. (In Russ.).

[16]H.I. Ansoff, "Strategic management", Wiley, New York, 1979, 236 p. 